\title{
ДОСВІД ВПРОВАДЖЕННЯ КРЕДИТНО-МОДУЛЬНОЇ СИСТЕМИ ОРГАНІЗАЦІЇ НАВЧАЛЬНОГО ПРОЦЕСУ 3 ОНКОЛОГІЇ НА МЕДИЧНОМУ ФАКУЛЬТЕТІ
}

\author{
Е. В. Олійник, Б. І. Шумко, Л. Я. Федонюк \\ Буковинський державний медичний університет, м. Чернівиі \\ EXPERIENCE OF IMPLEMENTATION OF CREDIT-MODULAR \\ SYSTEM OF ORGANIZATION OF TEACHING OF ONCOLOGY AT \\ MEDICAL FACULTY \\ E. V. Oliynyk, B. I. Shumko, L. Ya. Fedonyuk \\ Bukovynian State Medical University, Chernivtsi
}

\begin{abstract}
У 2009-2010 навчальному році на кафедрі онкології та радіології Буковинського державного медичного університету викладання дисципліни “Онкологія" на медичному факультеті почало проводитись за новою навчальною програмою “Онкологія” для студентів вищих медичних навчальних закладів III-IV рівнів акредитації (спеціальність: лікувальна справа, педіатрія, медико-профілактична справа), затвердженою МОЗ України, Центральним методичним кабінетом 3 вищої медичної освіти від 17 червня 2008 р. У роботі автори діляться досвідом впровадження кредитно-модульної системи організації навчального процесу (КМСОНП) з онкології на медичному факультеті.
\end{abstract}

Teaching of oncology at the Department of Oncology and Radiology at Bukovynian State Medical University was conducted according to the new curriculum "Oncology" for medical colleges, III-IV levels of accreditation (specialties: specialists, pediatrics), approved by Ministry of Public Health of Ukraine and The Main Methodological Centre for Higher Medical Education in 20092010 academic year.

Вступ. Сучасний інформаційний вибух в науковоосвітньому просторі диктує свої умови для зміни технології навчання. Інноваційні входження України в освітньо-науковий простір Європи передбачає нові гнучкі моделі організації педагогічного процесу та забезпечення високої якості підготовки фахівців, їх конкурентоспроможності на міжнародному ринку. Виникає необхідність якісної підготовки нового покоління викладацького складу 3 новим мисленням та новими підходами до організації навчального процесу, які грунтуються на досвіді кращих традицій української вищої школиу поєднанні з використанням новітніх технологій і досвіду країн Європи. Надзвичайно актуальною на даний час залишається проблема підготовки методичної літератури для студентів вищих медичних навчальних закладів України.

Тому осмислення досвіду впровадження КМСОНП 3 онкології на медичному факультеті нашого вузу допоможе проаналізувати результати цього педагогічного експерименту, усвідомити здобутки і врахувати помилки освітніх перетворень.

Основна частина. Сьогодні Болонський процес це робоче середовище для колективів вищих медич- них навчальних закладів України, в якому наявні як досягнення, так і проблеми. Дворічний досвід впровадження КМСОНП з онкології в Буковинському державному медичному університеті свідчить, що робити висновок про високу ефективність іiї реалізації в цілому поки що зарано.

Незважаючи на широкий загал вже існуючих фундаментальних джерел з питань онкології, які дещо застаріли, а також враховуючи суттєве збільшення частки позааудиторної самостійної роботи студентів відповідно до вимог Болонської декларації на кафедрі онкології та радіології авторським колективом створено навчально-методичний посібник "Онкологія", який рекомендований Центральним методичним кабінетом 3 вищої медичної освіти МОЗ України як навчально-методичний посібник для студентів вищих медичних навчальних закладів IV рівня акредитації. Викладений матеріал у посібнику відрізняється методологічною спрямованістю, об'єктивністю, адаптованістю до вимог робочої навчальної програми i викликає зацікавленість у читача.

Значна увага у зв'язку з недостатньою кількістю літератури приділяється комп'ютерним технологі-

(с Е. В. Олійник, Б. І. Шумко, Л. Я. Федонюк 


\section{ВДОСКОНАЛЕННЯ ВИЩОЇ МЕДИЧНОЇ ОСВІТИ}

ям, підключення до мережі “Internet". За допомогою цих систем доступними стають контакти в режимах on-line i off-line з іншими навчальними закладами країни. 3 власного досвіду можемо сказати, що для удосконалення самостійної роботи студентів $є$ актуальним активне впровадження електронних методів навчання, але разом $з$ тим хочемо зазначити, що використання мультимедійного електронного способу навчання не здатне замінити того, що може і повинен отримати студент на практичних заняттях безпосередньо біля ліжка хворого. В цьому плані ще одним стимулом прояву рівня творчого пізнання є курація хворого та наступне написання історії хвороби.

Система контролю на кафедрі суттєво не змінилась при впровадженні КМСОНП. Також, як і раніше, на кожному занятті викладач оцінює підготовку кожного студента. Завдання уніфіковані і стандартизовані. Із переліку питань, на які необхідно відповісти студенту при виконанні завдання, виділені основні. Неправильна відповідь на них виключає позитивну оцінку знань студента. У кожному завданні наведена шкала оцінювання, що виключає суб’єктивізм зі сторони викладача.

Ретельний аналіз теперішньої ситуації порівняно 3 даними, отриманими до введення КМСОНП, вказав нам на такі позитивні зміни:

а) зменшення кількості пропусків практичних занять та лекцій;

б) більш регулярна підготовка студентів до практичних занять;

в) стабільність та невелике підвищення середнього балаз дисципліни;

г) покращились результати складання ліцензійного іспиту “Крок”.

Крім позитивних змін, звертаємо вашу увагу на недоліки:

\footnotetext{
Лiтература

1. Казаков В. М. Новітні тенденції розвитку європейської медичної освіти / В. М. Казаков, О. М. Талалаєнко, М. Б. Первак // Медична освіта. - 2009. -№ 2. - С. 40-44.

2. Основні засади розвитку вищої освіти України в контексті Болонського процесу / [М. Ф. Степко, Я. Я. Болю-
}

а) необхідність викладачу проводити щоденне оцінювання студентів у великих групах поступово почала відтісняти на другий план більш важливу частину заняття;

б) сучасний студент добре навчився вирішувати тести, але в нього бракує клінічного мислення та практичної підготовки, знання його стали менш стійкими;

в) студент має право, не склавши попередній модуль, продовжувати вивчення наступного. В такій ситуації лише сильний студент в змозі успішно завершити засвоєння минулих розділів та оволодіти поточним матеріалом, для всіх інших це важко і мало реально. Тому що якщо їм і вдасться це зробити 3 наступної спроби, то сумарний рівень їх знань та практичних навичок не буде достатній для подальшого навчання та професійної діяльності.

Порівнюючи результати семестрової успішності на медичному факультеті з дисципліни “Онкологія”, ми звернули увагу на зниження якісної успішності студентів за тривалий період навчання в цілому, та зменшення кількості відмінників. Тенденція до такої успішності характерна для Європейського простору вищої освіти, де якість підготовки майбутнього фахівця визначається його рейтингом, а не відсотками відмінних оцінок у додатку до диплома, як в Україні.

Висновок. Підсумовуючи все наведене вище, ми хочемо підкреслити, що незважаючи на деякі недоліки КМСОНП з онкології, відповідно до вимог Болонського процесу для студентів вищих медичних навчальних закладів III-IV рівнів акредитації (спеціальність: лікувальна справа, педіатрія, медико-профілактична справа) дозволить підняти лікаря на якісно новий рівень клінічного мислення, здатного з позицій міждисциплінарного підходу системно та комплексно вирішувати профілактичні, діагностичні, лікувальні й реабілітаційні завдання лікарськоїпрактики і бути конкурентоспроможним на міжнародному ринку праці.

баш, В. Д. Шинкарук та ін.]; за ред. В. Г. Кремня. - Тернопіль, 2004. - 147 с.

3. Вища освіта України і Болонський процес : навч. посіб. /за заг. ред. В. Г. Кремня. - Київ-Тернопіль : Богдан, 2004. $368 \mathrm{c}$. 